\title{
所澤町東方武藏野堂地の地下水, 特に宙水々
} 淺以衹地の成因, 聚落立地との關係*

\author{
吉 村 信 吉
}

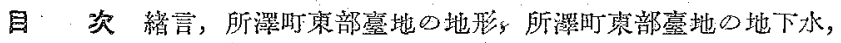

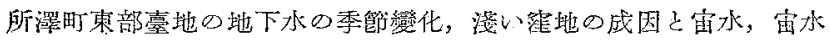
域乞聚落，結論，參考交䖈

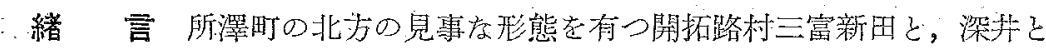

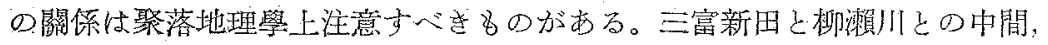

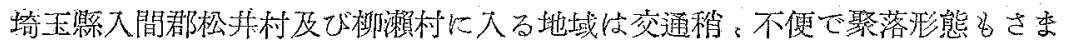

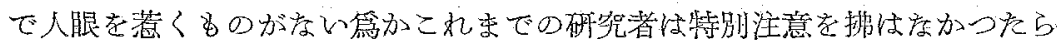
しく報文の發表されを8のを見ない。

著者は昭和 13 年 5 月偶，本地域に立入つてから地下水，聚落䂗究上武藏

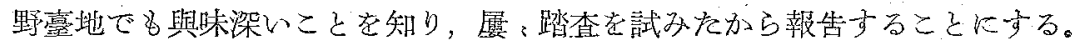
本支で取挍つた地域と地理學的に一體と看做される下新井，牛沼（共に松井

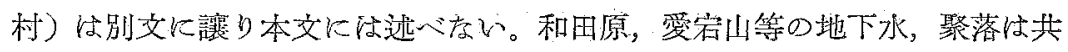
同研究者古川答爾氏气共に别に發表する豫空でするかららこら亦簡略に取报つ

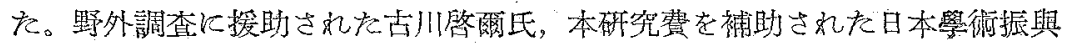
會に愿く感謝の意を表する。

\section{所澤町東部瞢地の地形（第 1,8 圖）}

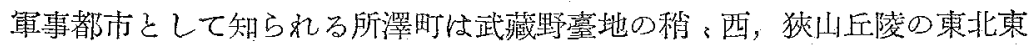

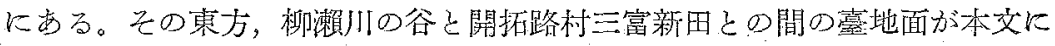

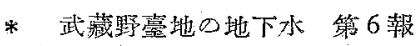


取扱ひないと思ふ地域であるが，別交に还心゙る下新井，牛沼々除外した。 本地域の南加ら東北にか子ては塽山丘陵に源を發する延長川柳瀨川（久米 川）の谷がある。これは武藏野臺地西部で最大であつて谷底め幅 $600 \mathrm{~m}$ ，谷 壁の高さ $20 \mathrm{~m}$ 冈外である。北側面㤌柳瀨川の側侵玲に上つて直線的急崖を 袁し，所々と好露頭を認めるととが出來る。

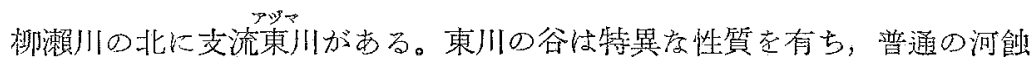

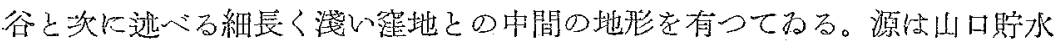

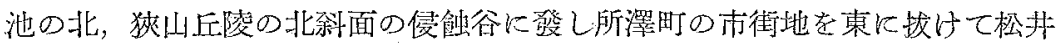

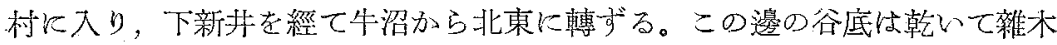
林や桑烟等になり，河渠には本常流水がない。楖瀬村日比田火於て西方牛沼 新田から來る支流を合し，敄ヶ谷を經て坂之下で楖瀨川に入る。坂之下の附 近では通常の谷のやらに河渠は杪礫愿を切り常時流水がある。

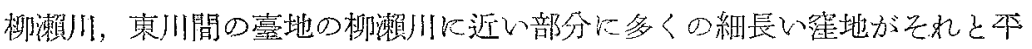
行してるる。末端は深い柳瀨川の谷に大るので相當に深く执られてわるが， 大部分は淺く，平時底は乾いてるる。例へば下安松の小字中新井の北の変宕

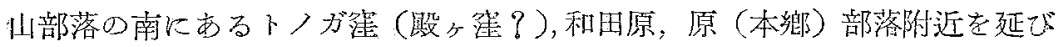

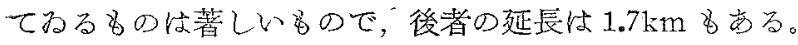

東川より北の臺地には上鲾刃は北永茾のや弓計畫的新田聚落(開拓路村)

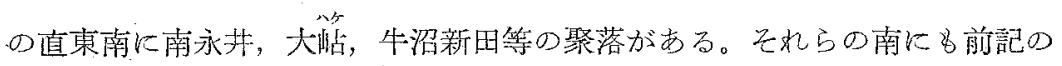

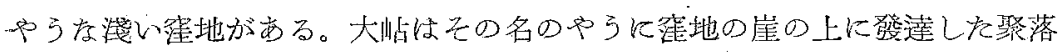

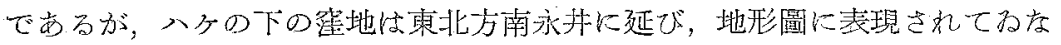

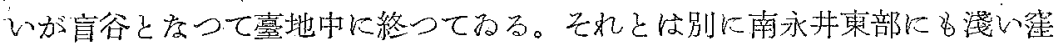

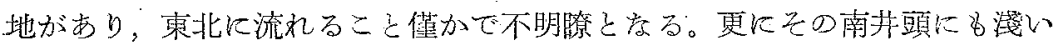

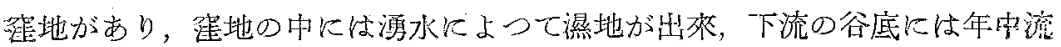


れがある。

\section{所摆町東部音地の地下水}

著者任昭和 13 年 5 月 30 日上富占り南永茾，大阽，日比出，牛沼新田， 牛沼方面を踏查し，武藏野臺地としては複雜京地下水系をなしてるることを 知つを。越总て同 6 月 23 日には所澤町方ら大和田に至る街道に沿心諸部落 で特色ある地下水を觀察し，愛宿山，及び和田原の一部では聚落と井月列を が距り紊がら平行するのを見た。同7月6日豪雨後の再調查の際には愛岩山 方面の地下水面の異常上景を測定した（吉村 1939）。同9月22日に性沼,

(上管松) 原方面を調查した。

昭和 13 年 $11 ， 12$ 月の武藏野臺地地下水一竍調枱の際，12月3 日南永斗， 大岾方面，12月11日所澤，大和田街道方面を精查した。翌年 3 月 26 日に 恪兩方面を再調查した。同年 10 月古川倁爾氏は愛宿山，和男原の宙水を精

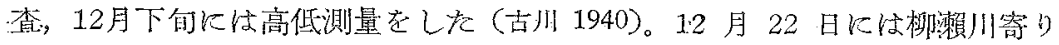
の部分を踏查した。かやうに調查国数は多いが，何分こ」だけを研究したの

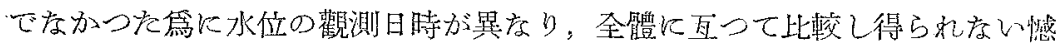
みがある。

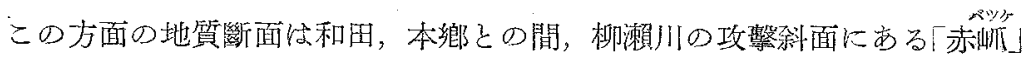

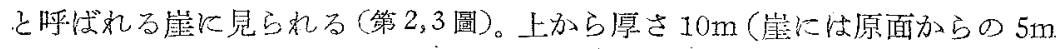

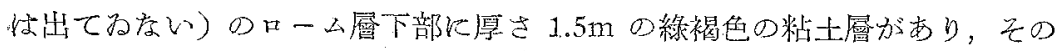

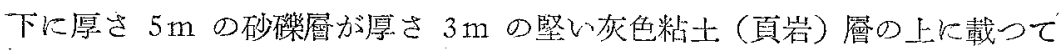

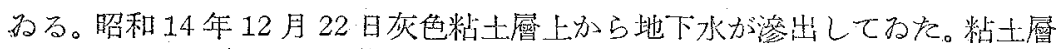

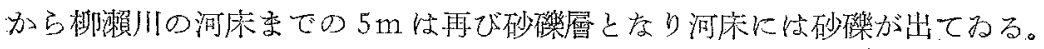

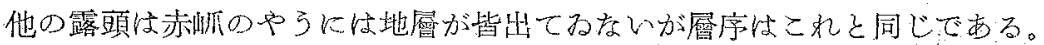

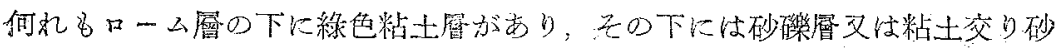




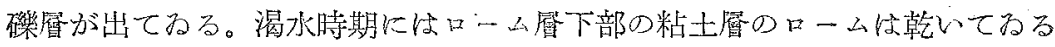

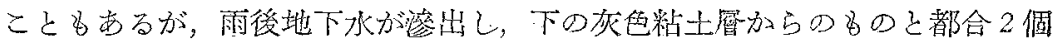
所方ら涌出してるる。

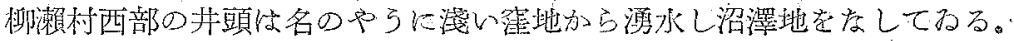

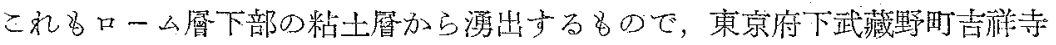

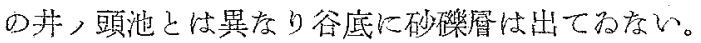

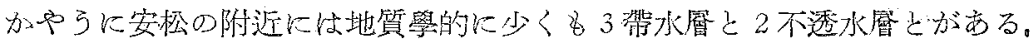

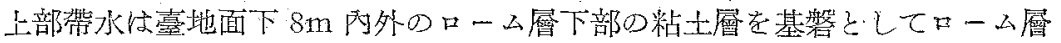

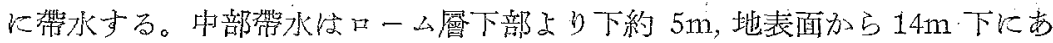

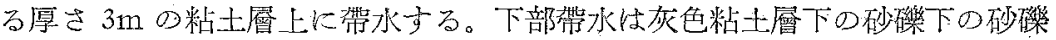

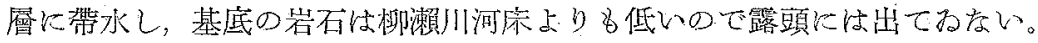

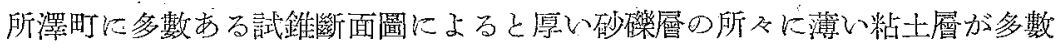

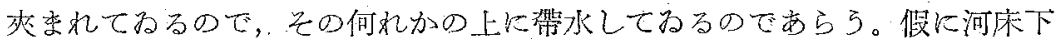
$1 \mathrm{~m}$ の所にあるにすれ他表面下 $24 \mathrm{~m}$ となる。

以上は露頭に於ける觀察に基いた分類であるが，牛曰に就いて行つた實測

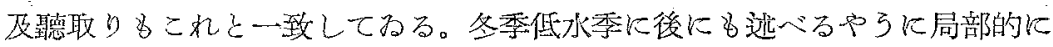
地表面下 $6 \mathrm{~m}$ 位に需水があり，井底が $7 \mathrm{~m}$ にある淡い汼が存在してるる。井

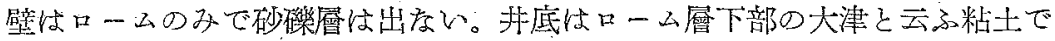
止めて㐫る。この此下水は上部帶水に相當してわる。

上に迅べ淺井の近くには大井月又は深并月と呼ばれる深井がある。地表

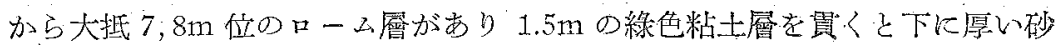

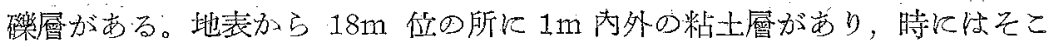

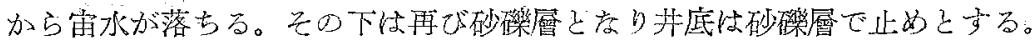

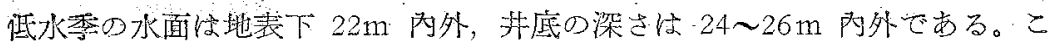


れな下部帶水に相栄してるる。

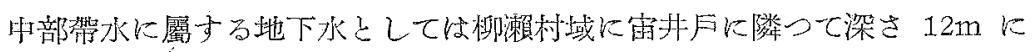

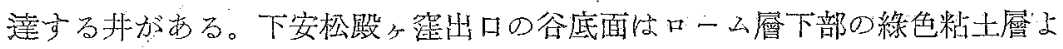

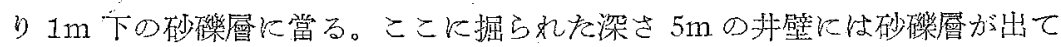

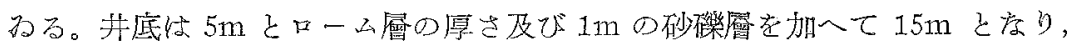
上記の中部带水の深さとよく一致する。

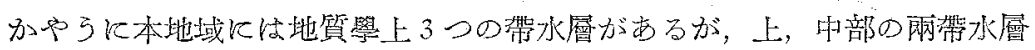
は水の供給が少い第飞局部的飞湛水するのみで，低水期飞怯下部帶水のタが

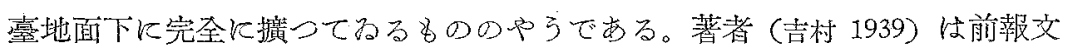
飞本地域の地下水を宙水，上部本水，下部本水学區别乙たの驻，夫之上，中，

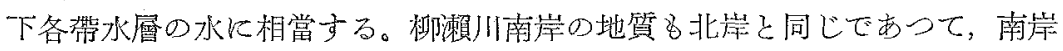

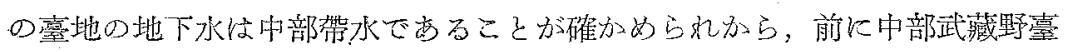
地の本水を西部臺地の上部本水乞地下水學的に等しいとしたのは地筫學上か ら多不當でないやうで考。。

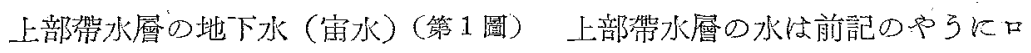

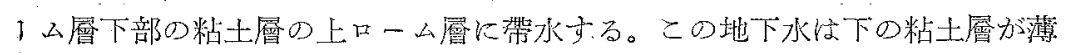

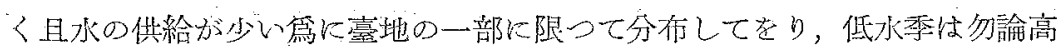

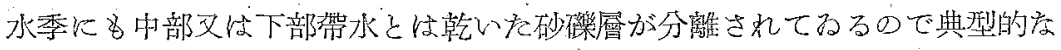

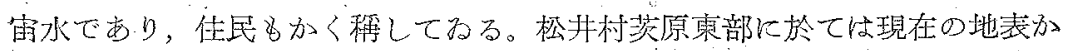

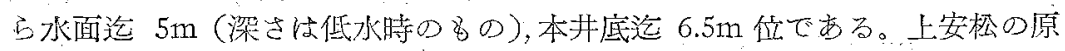

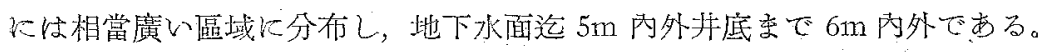

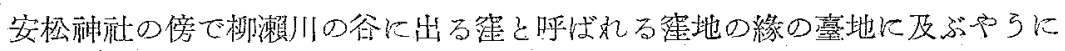
兒える。

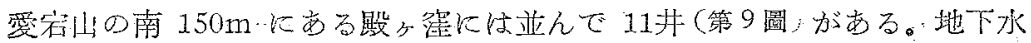




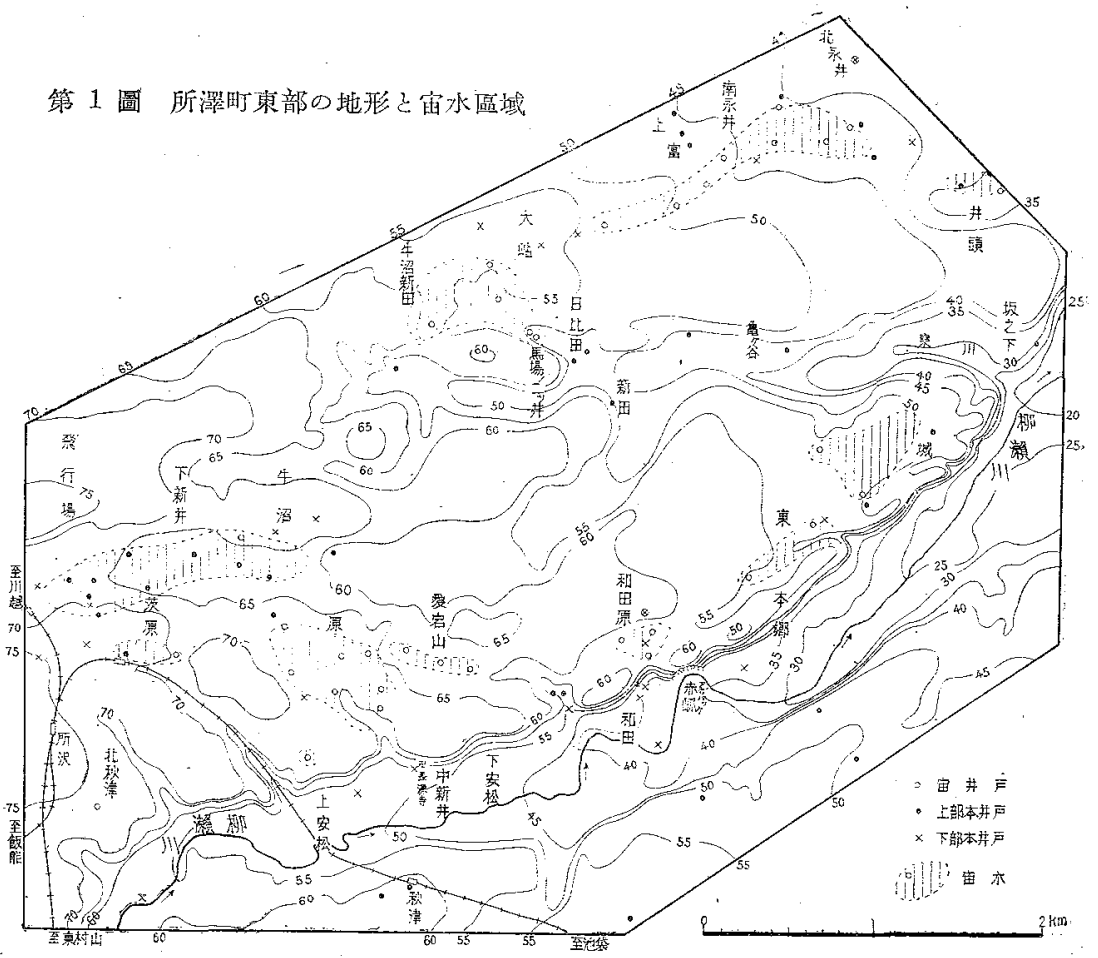

面の深さ3〜4m，井底の深さ 5〜 7 m である(古川氏测定)。これと柳瀨川迄

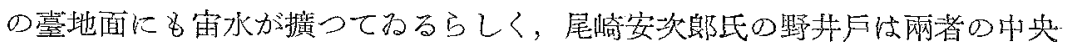

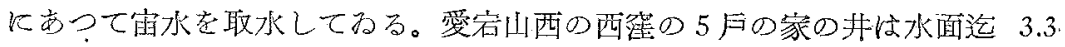

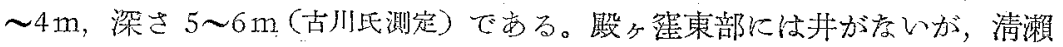

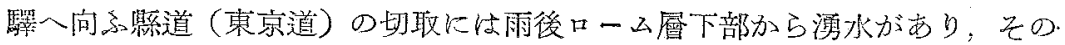

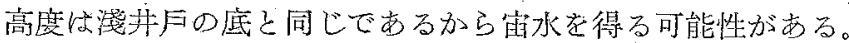

和田原に8 16 の宙斗月がある(第10圖)。地下水面の深さ 5 〜 $8 \mathrm{~m}$, 井底迄 5.5 8.4m（古川氏測定），近年深并月が出爽てからは水持ちが朢く店つて來た

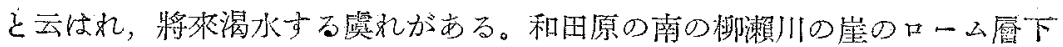


部の粘土㾖からは雨後汿水があり宙水が漏出してるることが知られる。

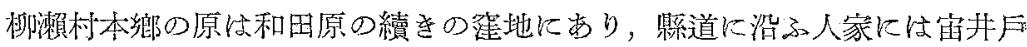

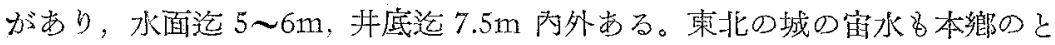

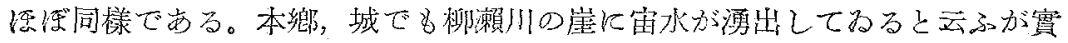
地に踏查してる疗い。

松井村牛沼新田の地下水面の深さは $4.5 \mathrm{~m}$ 位, 茾底迄 $6 \sim 7 \mathrm{~m}$ である。之

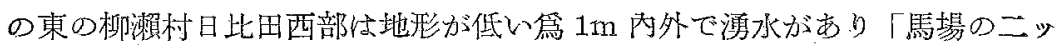
井」のやうに弘法大師の汿水傅說のある茾が數中に 2 つ並んでをり，附近に 踐い牪8，三あ尚。

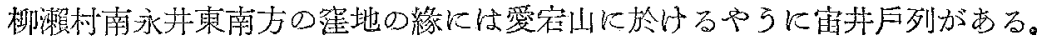

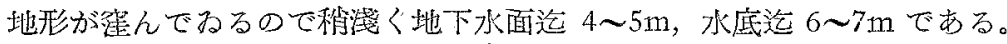

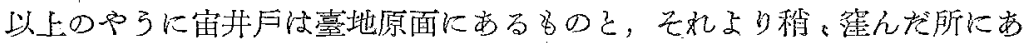
る8のとでは多少の染㨹はするが，侵蝕されない原面からすれば氷面迄 $6 \mathrm{~m}$

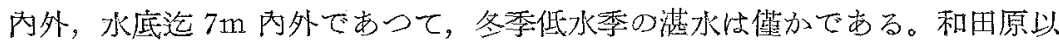
外では餘り渴水することは去い。

本研究地域ではローム角下部が粘土質化してるる。粘土層の表面が蜜文 は粘土が厚く地下水の䆝透が妨げられれば局部的に帶水して笛水となる。一 方粘士磨が薄くて膤水し易く，又近くに低地があれば地質は同じでも崖から 湧出し去つて帶水し存いであらう。

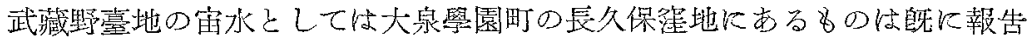

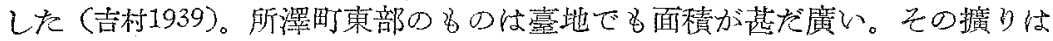

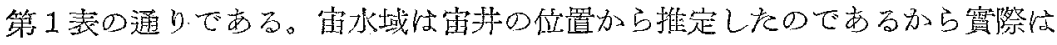

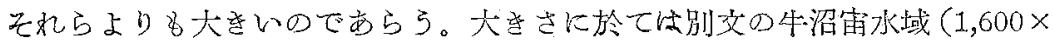
$300 \mathrm{~m}$ )には及方い。 
武藏野臺地以外では著

者亡山本氏 $(1936,38)$ が

于禁市北郊で研究した登

点宙水域 $(750 \times 250 \mathrm{~m})$ ，

辻本理學士 (1937) 少相

第. 1 表

表

\begin{tabular}{|c|c|c|c|}
\hline 宙水域名稱 & $\mathrm{m}$ & $\begin{array}{l}\text { 愊 } \\
\text { m }\end{array}$ & $\begin{array}{l}\text { 低水季の地下 } \\
\text { 水唒の媣さ现 }\end{array}$ \\
\hline 苂 … & 400 & 100 & 5 \\
\hline 原 (上晏松) & 800 & 400 & $5 \sim 6.5$ \\
\hline 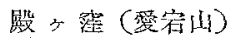 & 550 & 150 & $3 \sim 4$ \\
\hline 和＼cjkstart田 & 350 & 200 & $5 \sim 8$ \\
\hline (梦 & 650 & 150 & $5.5 \sim 6.5$ \\
\hline 城 & 600 & 350 & 5 \\
\hline 南永节，榳下 & 1,700 & $300 \sim 150$ & $4 \sim 5$ \\
\hline 日比田，胙沼愘田 & 800 & $400 ?$ & $1 \sim 4.5$ \\
\hline
\end{tabular}

大沼新田宙水域 ( $450 \times$

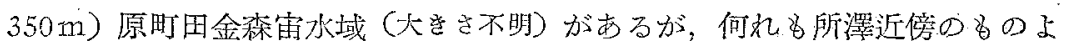

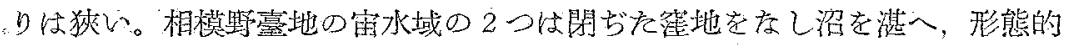
差前見られる。

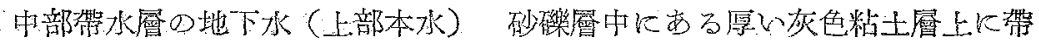

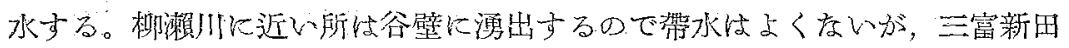

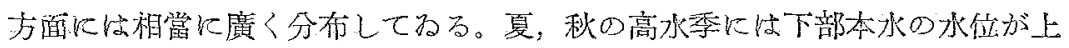
景し一本地下水と一緒儿索多1 つ0地下水面を形成するが，冬の低水期に怙

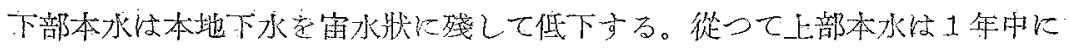

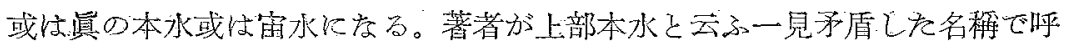

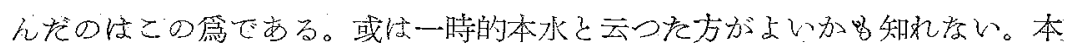

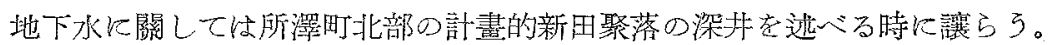
昭和 13 年 6,7 月の豪雨による増水によつて下部本水と合したことは上䈏に 於ける觀祭に基いて先に迅心゙老通りである(吉村 1939)。

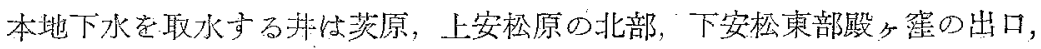

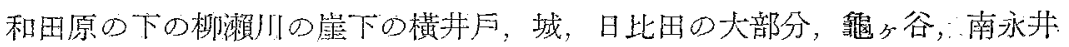

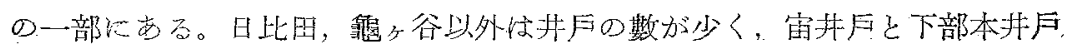




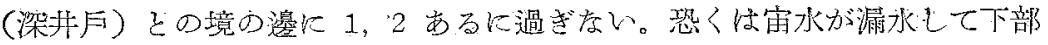
本水に落ちる間に一時的に溜留するのであらう。本我を取る大部分の升络渴

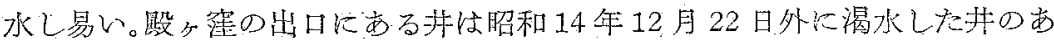
るを聞かない先に早く多枯渴した。和田原の下の楖瀨川の崖下にある粠茾戶 も近年汽使用されてタたが，水量が不足とたつたので中 2 家では前庭に深さ

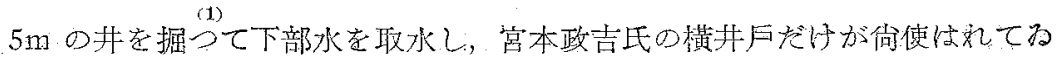
万(第 2 圖)。

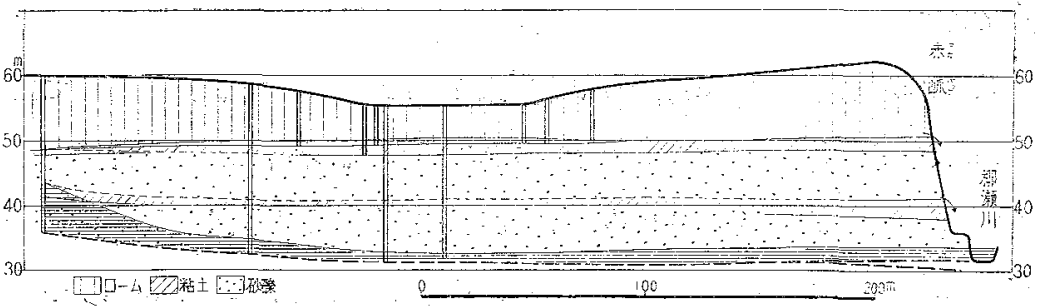

管 2 圆

城にある1井は昭和 13 年 12 月，南永井の關根彌氏の井は昭和 14 年 3 月

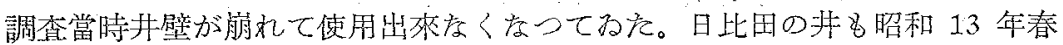
の低水時には西にある宙井戶の外は渴水し，井底浚浆子效がまく，菂井月の

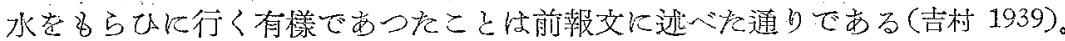

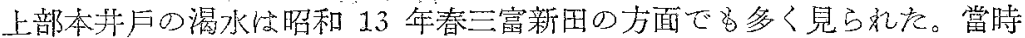

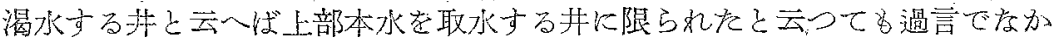

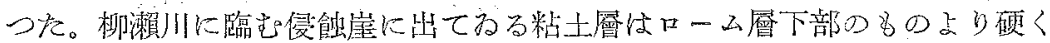

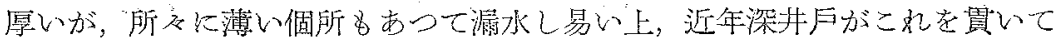
造られたので益: 水持ちが惡く症つたのであらう。

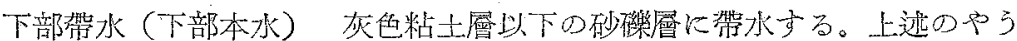

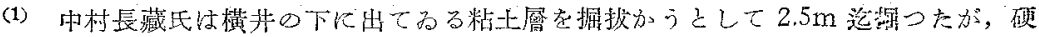
く厚いので此し前庭に現在の茾を掘つたよ云ふ。 


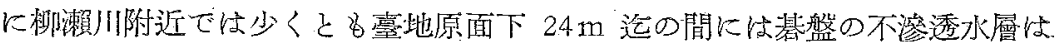

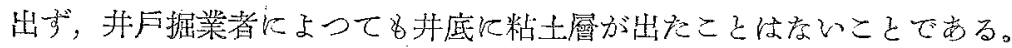

夏季高水季には水位著しく上暴し上部本水乞一緒になる。平掌は水面迄 25 $\mathrm{m}$ 8 ある茨原西部の其同斗（現在廢斗）は昭和 13 年 7 月 6 日には $15.3 \mathrm{~m}, 9$

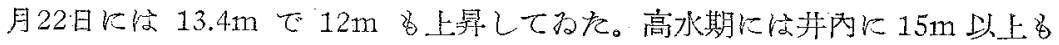

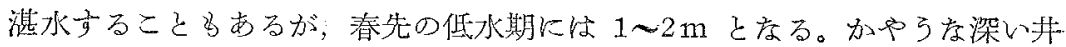

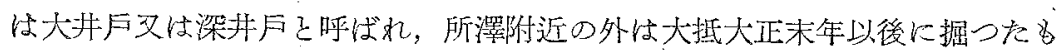
のである。

荻城に法酉部にあつて前記のやうに深さ $27 \mathrm{~m}$ に達する。上安松原では西

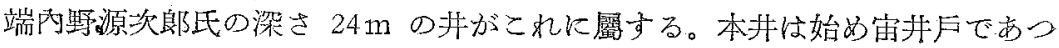

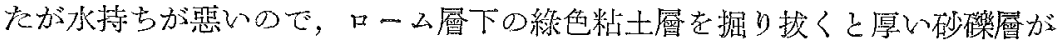

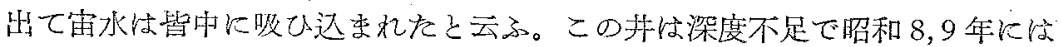
1 年間，昭和 13 年春には 3 月間水を殘さず，著者の研究した深井戸で渴水 した㫿一の例でする。本井の水位は昭和 14 年 1 月來定期觀測中で結果统別 に報告する積りである。

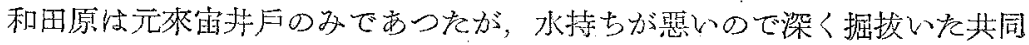
月が大正 14 年に出來，次いで3つの深年曰が掘られた。深さ地形により 少し異なるが 21〜26m（古川氐测定）で何れも深さ $18 \mathrm{~m}$ で粘上㾇を貴き，

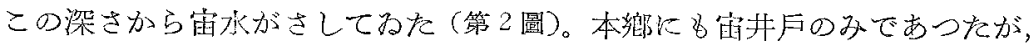
昭和 13 年 12 月始的て深さ $23.7 \mathrm{~m}$ の本井戶が掘られれ。掘終つた時に行合は

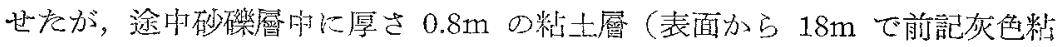

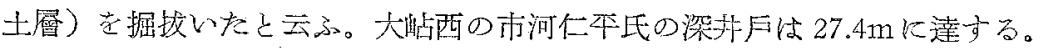

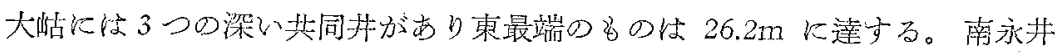
の南の大井月秒、淺く $17 \sim 18 \mathrm{~m}$ 内外である。南永井の北 $500 \mathrm{~m}$ の北永茾 


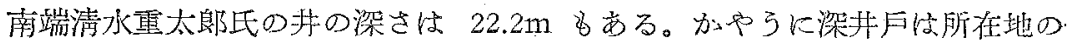
地形により多少の淺深は岁るが 24〜27m に澾する。所澤町や三富新田に南

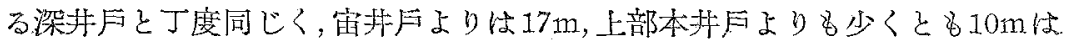

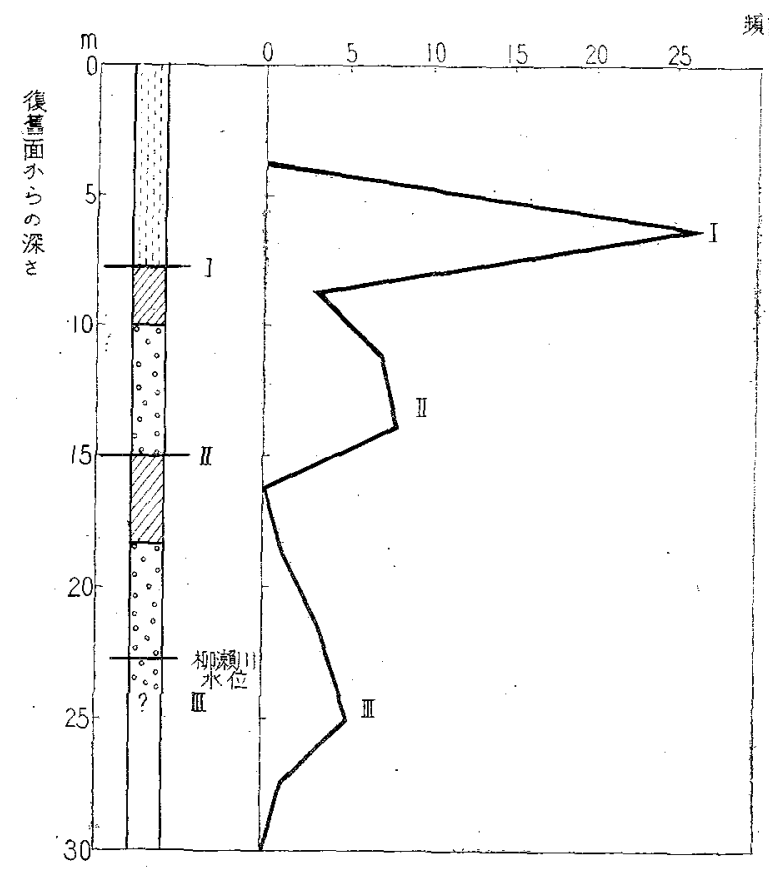

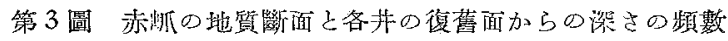

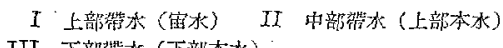
III 下部乖水（下部本水）

頻數 深い。

本矿觉地域に

ある地下水に 3

䅜の采統がある.

こと惊冬季低水

期の地下水面の

深去加方推定

される。开州

在地の局部的の

地形の影響老除

去宗第に地形

復舊圖を作り，

それからの潹さ

に㨘算してふら

各哚展階級に屬

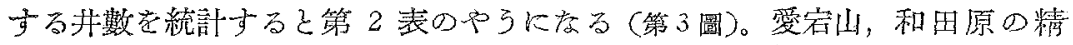

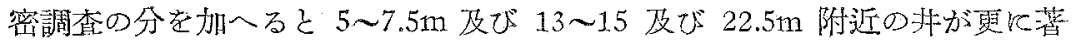

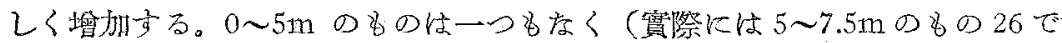

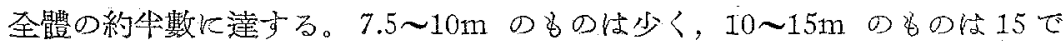

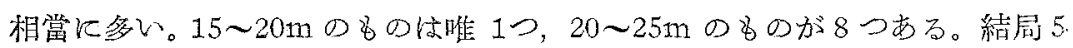

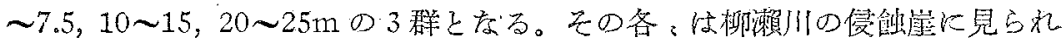


る復舊面下 $8 \sim 9 \mathrm{~m}, 14 \mathrm{~m}$ にある粘土曆。 上の帶水, 最後の\&のは楖濑川の水面(復 舊面下 $23 \sim 24 \mathrm{~m}$ ) : と一致生る。井四の分布 が偏在してるるから地下水面等高線圖を 精密に引くこをは困難である。冬季低水 時に於けるるのは第4圖のやらである。

\begin{tabular}{|c|c|c|c|}
\hline $\mathrm{m}^{\text {d }}$ & 頻度 & 深 $\mathrm{m}$ & 頻度 \\
\hline $0 \sim 25$ & 0 & $15 \sim 17.5$ & 0 \\
\hline $25 \sim 5$ & 0 & $17.5 \sim 20$ & 1 \\
\hline $5 \sim 7.5$ & 26 & $20 \sim 22.5$ & 3 \\
\hline $7.5 \sim 10$ & 3 & $22.5 \sim 25$ & 5 \\
\hline $10 \sim 12.5$ & 7 & $25 \sim 27.5$ & 1 \\
\hline $12.5 \sim 15$ & 8 & 䚺 & 54 \\
\hline
\end{tabular}

上部帶水（宙水）宙水け本筫的に連續した地下水等亩線で結ぶべきでな いから圆中に個长の地點の数字の文揭㚈た。宙水地下水面は西南西から

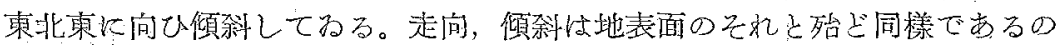

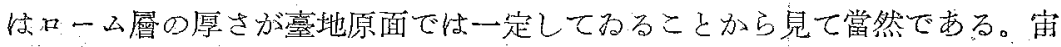
井月の近くに下部本井月がある所で网方の水位差柱次のやうである。

原（上安松）14m？ 和田原 15 16m, 原（本鄉） $16 \mathrm{~m}$ ，牛沼新田 $16 \mathrm{~m}$, 大呫 $16 \mathrm{~m}$

何礼多 $15 \mathrm{~m}$ 內外で，雷水面怡下部本水面と大體本行してわるもののやうで

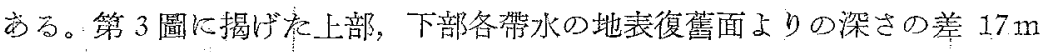

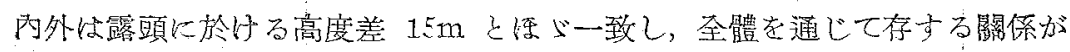
個々の宙水域に名成立することを示してるる。

中部舆水（上部本水）を敢水する井の分布が極限されてみて，地下水等高

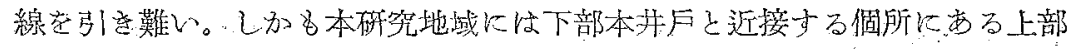

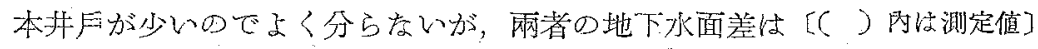

(上安松) 原 $6 \mathrm{~m}$, 日比田 $(8 \mathrm{~m})$, 龜s谷 $(7 \mathrm{~m})$, 城 (10m?), 上富 $7 \mathrm{~m}$ で大體 7〜8m 内外である。これ亦地下水面は下部本水面と本行するらしい。 兩者の高度差は露頭に於忷子觀察社よ。7.5m，地下水面の深さの頻度曲線 から得られた $10 \mathrm{~m}$ と大體一致してるる。 
下部帶水 (下部本水) 資料怡餘り多くないが，关礼から引いを等高線は 第 4 圖のやうである。走向は北西少ら東南東，傾斜は地表傾斜之殆ど同じで るが少し緩い。测定點は少いが地下水面は柳瀨川附近を除を平面に近い。

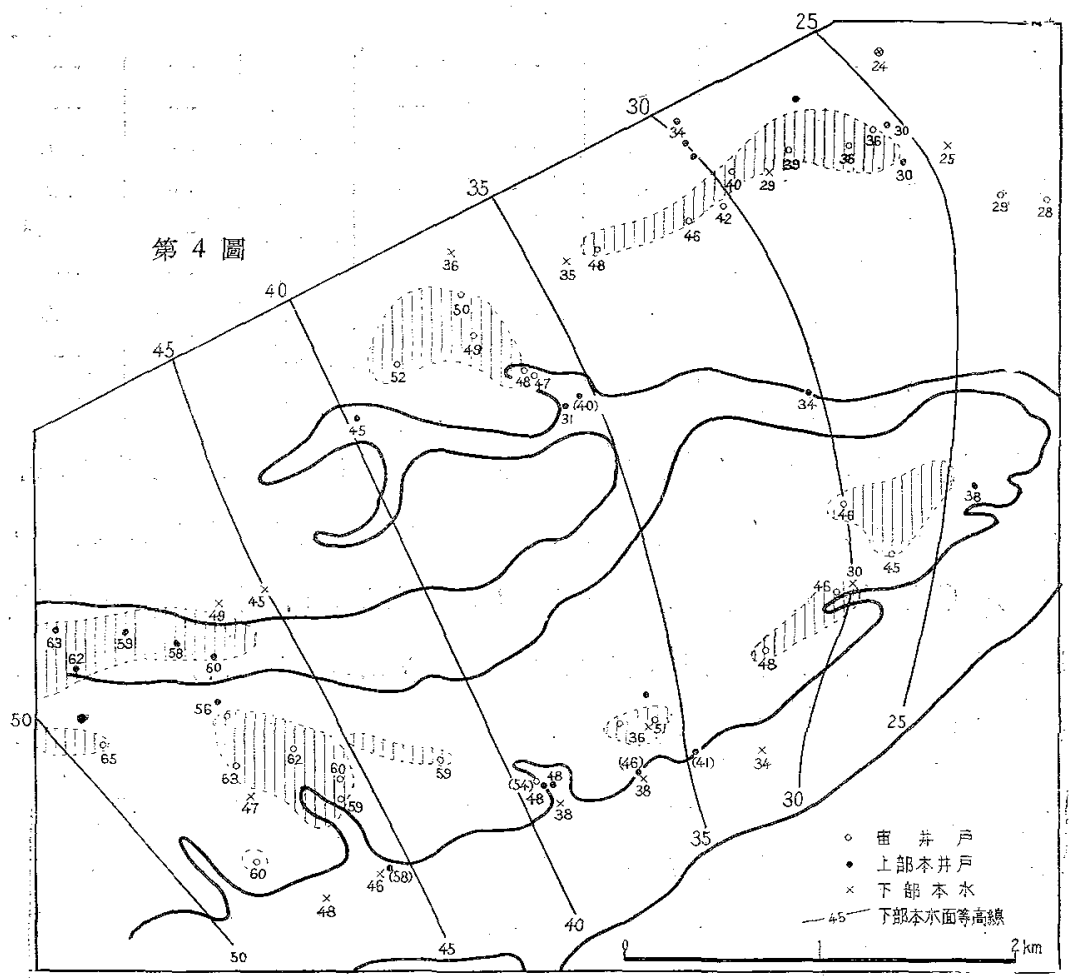

このことは悡の多い北方三富新田に然て在つきりと云八る。地形を考虑せず

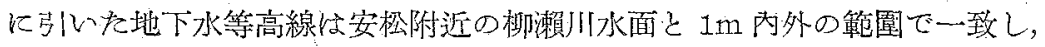
下部本水恄楖瀨川と平衡を保つてるることが推定される。

\section{所澤町東部臺地の地下水の季節變化}

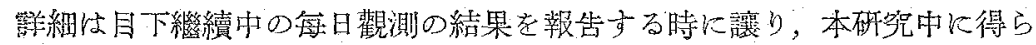
れれ結果のみについて述心゙る。第了表に種及の月日に測定しえ結果を揭げる。 


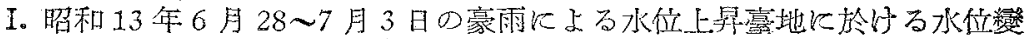

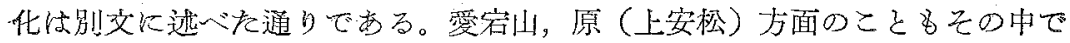

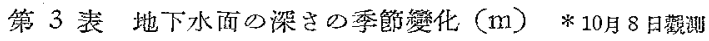

\begin{tabular}{|c|c|c|c|c|c|c|c|c|c|c|}
\hline $\begin{array}{l}\text { 婹言 } \\
\text { 番號 }\end{array}$ & 場 & & 所 & $\begin{array}{l}\text { 事底选 } \\
\text { 深已 } \mathrm{m}\end{array}$ & $\begin{array}{r}1123 \\
1938 \\
\end{array}$ & VII 6 & IX 22 & 近 11 & $\begin{array}{l}\text { III } 26 \\
1939 \\
\end{array}$ & $\times 20$ \\
\hline 30 & & 城 & & 7.4 & 4.5 & - & - & 5.3 & - & - \\
\hline 29 & 本 & & 鿾 & 7.4 & 4.5 & - & - & 6.5 & - & - \\
\hline 28 & 和 & 田 & 原 & 24.7 & 22.5 & - & $\ldots$ & 21.0 & - & 21.6 \\
\hline 27 & & " & & 6.4 & 4.7 & - & - & 6.1 & - & 5.2 \\
\hline 26 & 票 & 㝛 & 㞴 & 5.1 & 3.0 & 1.0 & - & 3.9 & - & $3.9 *$ \\
\hline 103 & 原 & （上姿 & 松） & 6.1 & - & 0.9 & - & 5.2 & 一 & - \\
\hline 311 & & $1 "$ & & 24.5 & - & - & 15.3 & 17.9 & 22.6 & 20.9 \\
\hline 104 & 荻 & & 原 & 6.5 & - & 0.9 & - & 5.1 & 5.1 & - \\
\hline 105 & & $"$ & & 27.0 & - & 15.3 & 13.4 & 17.5 & 24.2 & - \\
\hline
\end{tabular}

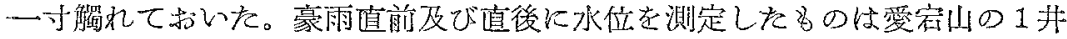
の多であつれが，豪雨前の水仕が本年の低水位と同じと假定すると，荻原の

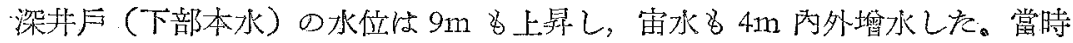
殿っ滗の底には濁水滔ふるして流れ，底部に近い所にある宙井户の地下水面 は豪雨 3 日後の7月6日に地面下佾 $0.9 \mathrm{~m}$ であつた。原(上安松), 茨原の宙 将月の水面は地表下約 $1 \mathrm{~m}$ に

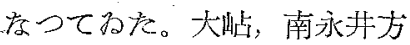
面は當時測定しはかつたが， 住民の榄によるる南の筀地に は湛水乙，箦地の科面の宙来

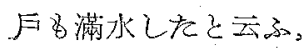

II. 昭和 13 年 12 月 3 日， 昭和14年3月26日刀南永并， 大岾の扡下水位の戀化昭和13

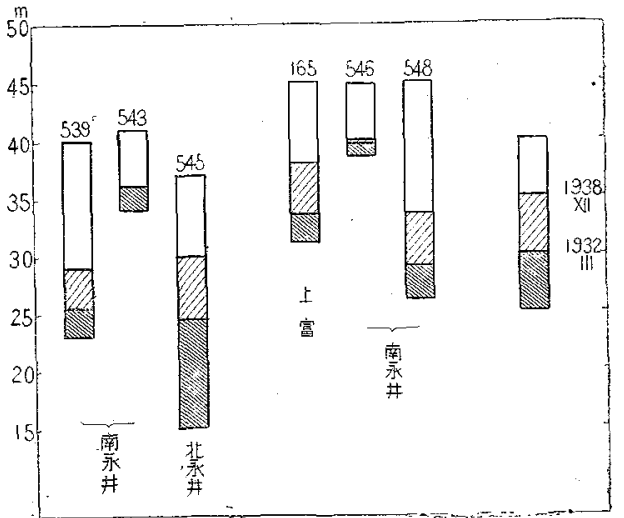

第 5 堛南永井宙水域附近の 1938 年 12 月 と 1939 年 3 月との水位變化 


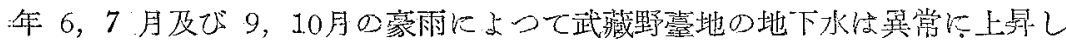
た。賞時南永井方面の賽测在し疼かつたので梁井户の最高水位はよくは念ら 庵かつたが，12月3日よりる1 $\mathrm{m}$ 位高かつた程度であつたやうである。宙

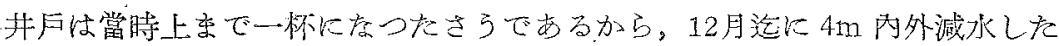
bしい。12月3日民翌年3月26日の115日閒の水位變化の分布领第6 圖の

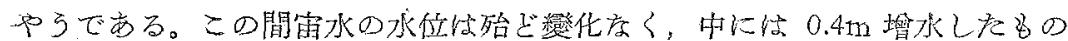

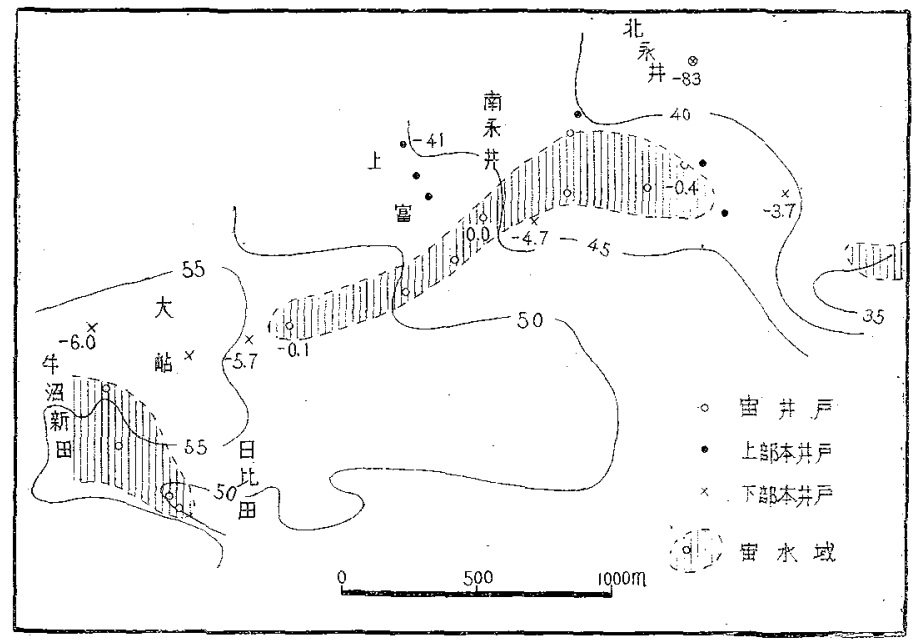

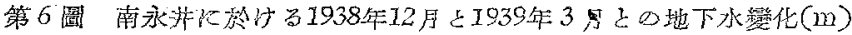

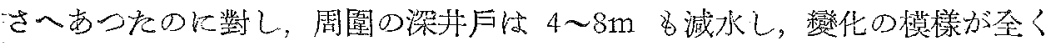

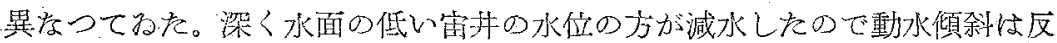
つて習加した。网種の茾の地下水面が部武藏野臺地にある地下水嫶(吉村 1940)のやうに連續してるるのとは正反数の結果となる。

兩者が帶水層を異にするとすれば容易に詰解出來万のであつて，宙水の水

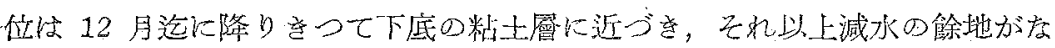

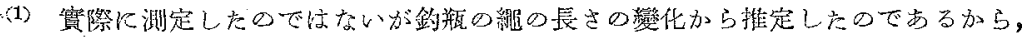
必ずしも不正確ではなからう。 


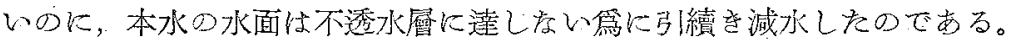

III. 茨原及び原(上安松) の昭和 13 年 12 月 11 日，昭和 14 年 3 月 26 日の

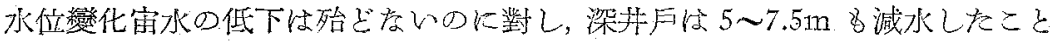

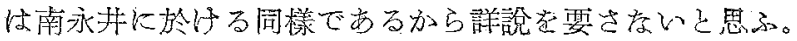

\section{荛い寉地の成因と宙水}

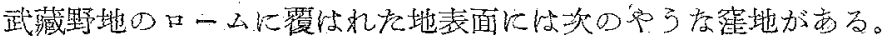

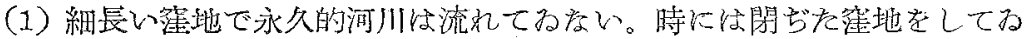
るが，底悢大抵は下流程低く存つてるる。底は烟に度り，水田は稀である。

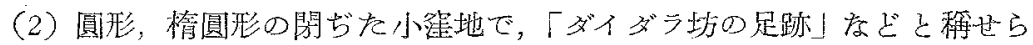

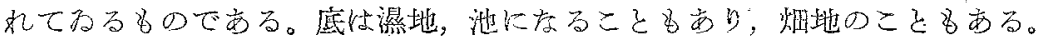

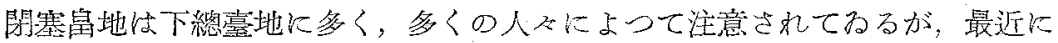
は花井，千葉兩氏（1939）の論支が出てるる。

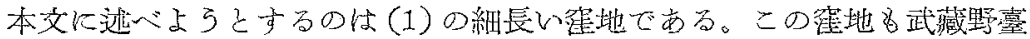

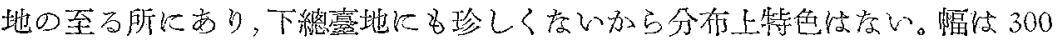

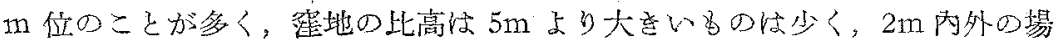
合が多い。谷形は，現河創谷のやうにU字を存し谷壁が急斜すること京い。

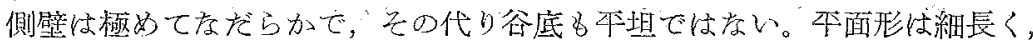

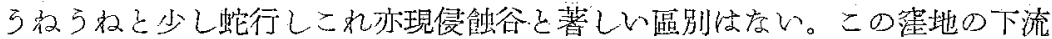

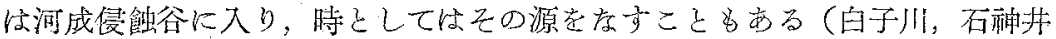
川上流，上野谷川》。時としては炊第に比高者減じて臺地中に跡を失ひ，大

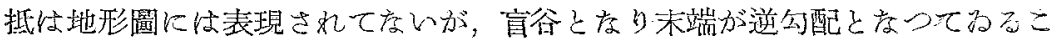
とさへ就る。

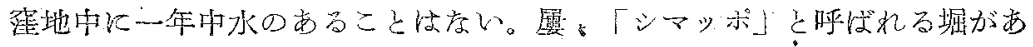

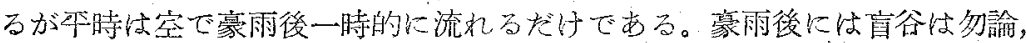




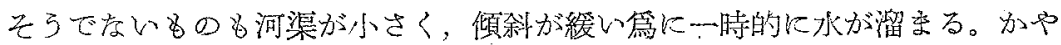

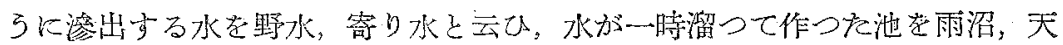
沼，氷溜り存どと呼ぶことがある。

第1圆を一見して分るや引に淺く長い寉地の所在な宙水域とよく一致して

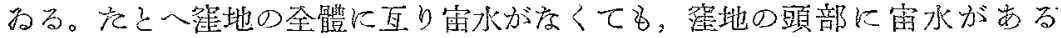

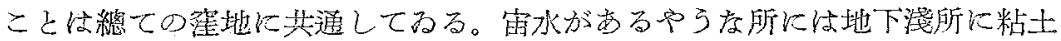

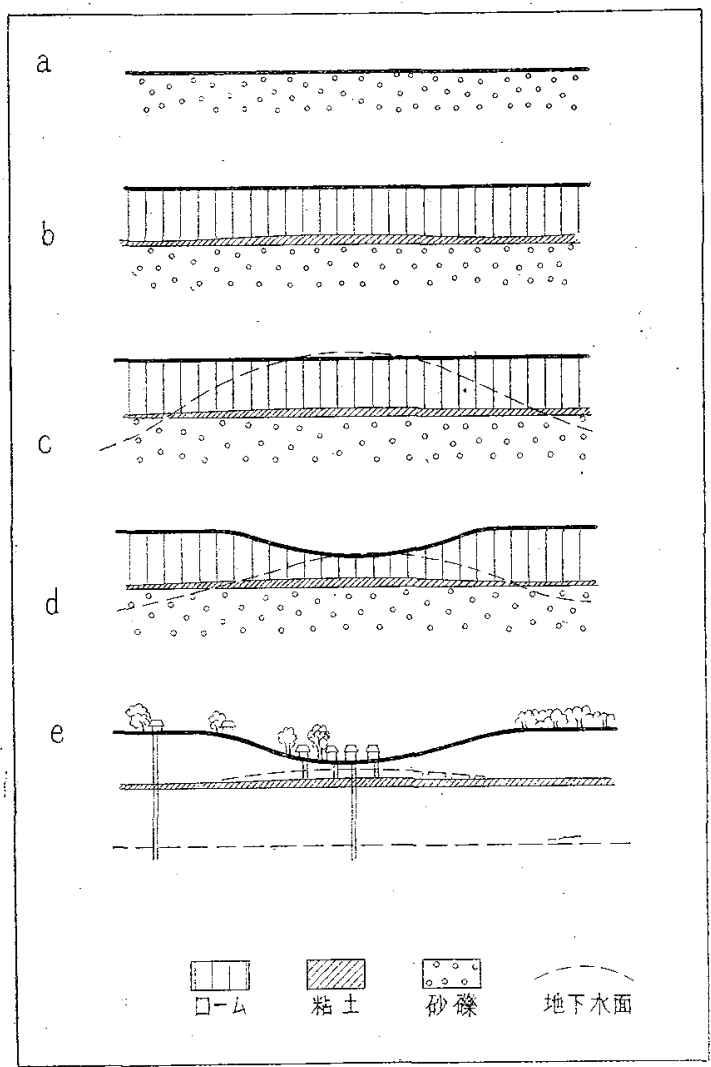

第 7 圆 港以溘地の成因々宙水，聚落立地 模式圖
廅があり，それが雨水

の滲透を斯げることは 䈏然で，宙水域に快豪 雨後に野水が出，その 侵蝕によつて篗地が生 ぶることは不思議では

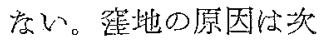
のやろに考へられる (第 7 圖)。

1. 所澤时の西に厚 い砂磷虞が堆積した。

2. 砂磞䊩最上部に 妘口-么堆積時代の始 比所飞子粘土，所 により砂が堆積しを (政 7 圆a)

3. 更口上に头山灰 が降つて小起优の地表 
の上に平坦旁䔻地原形を作つを(第 7 圖b)。

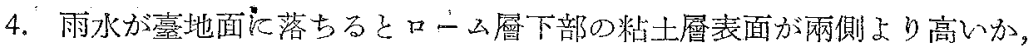

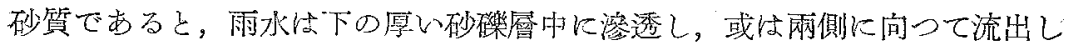

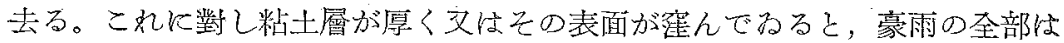

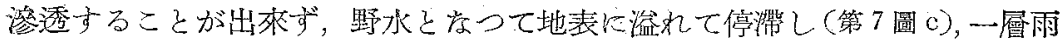

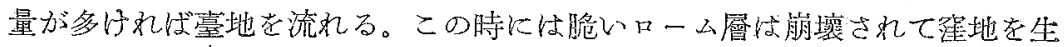
ずる（第7圖 d)。豪雨後の野水やとの侵飭は昭和 13 年 6,7 月市大豪雨の

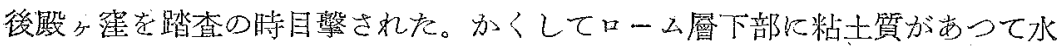

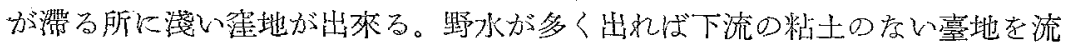

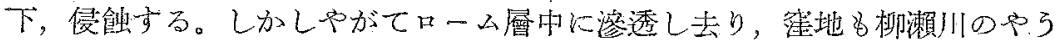
に深い河谷に出疼ければ，臺地上に姿を沙す。

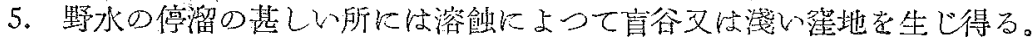
しかしこれは著者の想像を迅べたの゙充分の資料㤝有つてるない。

著者は别文に東京府北多摩郡保谷村上宿，田奥町谷月にある篗地の成因が 地下水堆によることを述心を(吉村 1940)。地下水陫家塚狀に隆起した地下水 が本水である點で宙水とは異なつてっる。しかし局部局に淺い地下水面をな し，䟠い篞地の生成に對する關係はこっに迅へたものと一致する。

\section{笛水域と聚落（第 8 圖）}

柳瀨川の西北に於ける方面の聚落の讀㩖による區分は毁に山崎 (1933)，能

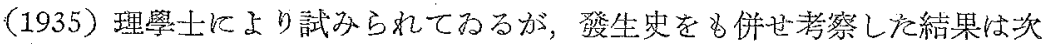

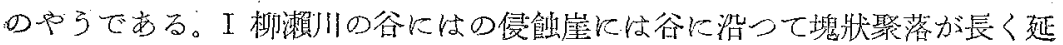

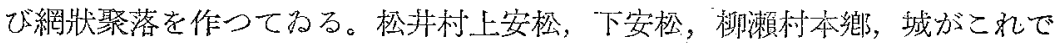
方る。新編武藏風土記稿によるとこれらは皆德川㭙代以前の古村に㺟し，正 保の古圖に出てるる。就本鄉は安松本鄉の意で安松でも最8古い所で今の 


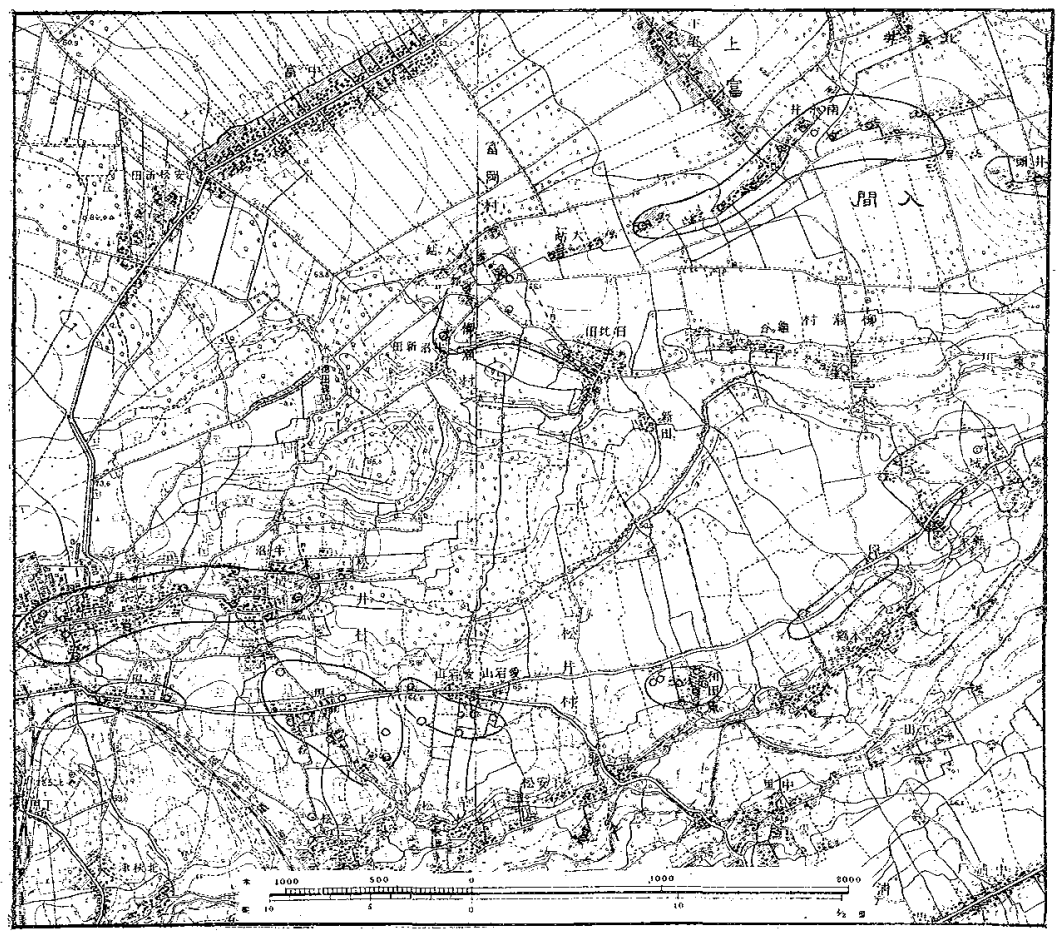

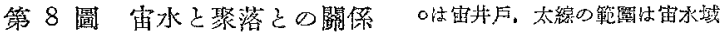

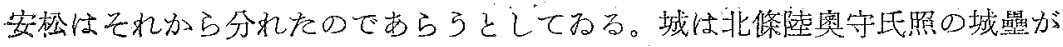

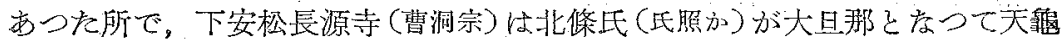

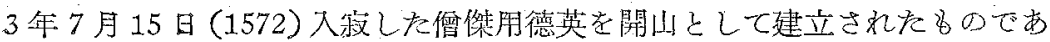
るから，少くとる戰國時代末期以前飞聚落があつたことは明かである。柳瀨

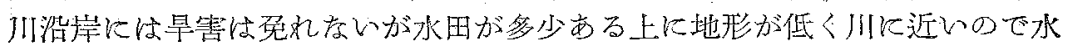

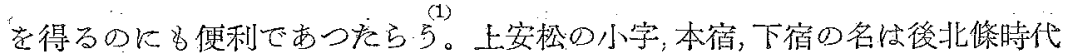
飞宿驩があつを名殘であらと云ふ。本鄉，和田の立地には前記のやうに崖

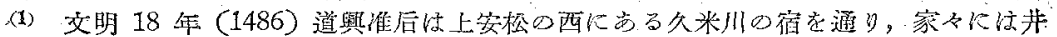

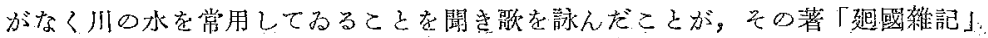
仙出てる。 


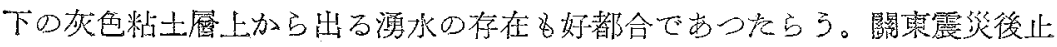

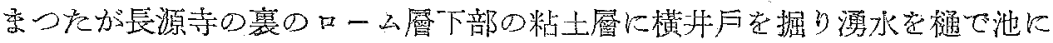
引以てタたと云ふ。

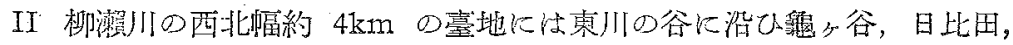

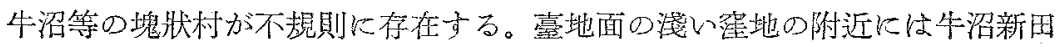

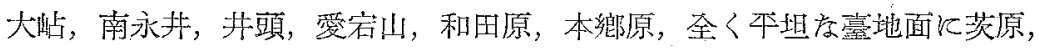

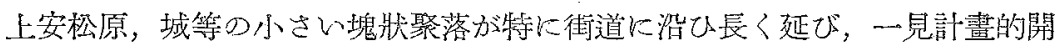

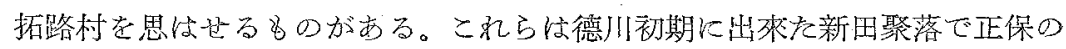

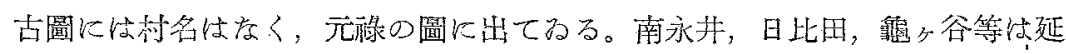

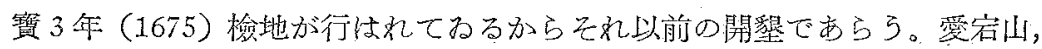
和田原は何れ子下安松の子村である。その發生の時期柱長源寺に保存される

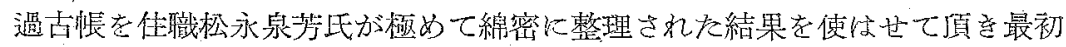

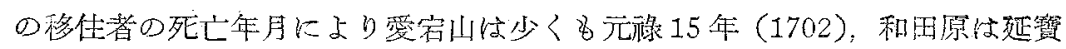

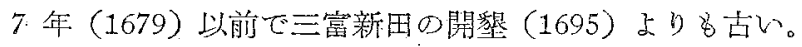

III 柳瀨川分ら西北 $4 \mathrm{~km}$ を距てを所には北永井，上富，中富等の規則正

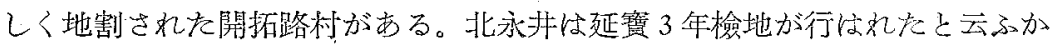

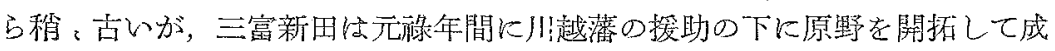
立したもので，前記自然發生的新田聚落より新しく生したものでする。が らに開拓を僬らせを原园の一として地下氷面が深いことが考へられる。

柳瀨川沿岸の苦聚落と三富等の計畫的新田聚落との間に自然發生的を新田

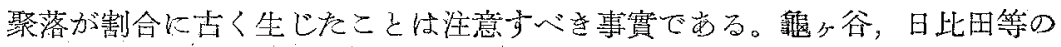
立地は東川の谷と關係付けられる。侻しとの他の聚落はもしも地下水面が三

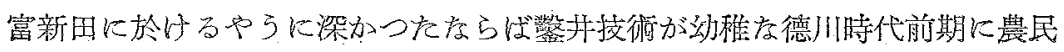

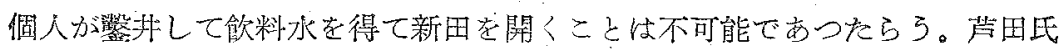




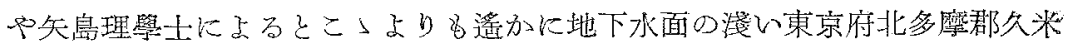
村，大沿田新田の井(昭和13 年12月 3 日の實測飞よると地下水面の深さ 7.1 $\mathrm{m}$ ，壮底の深さ $10.4 \mathrm{~m}$ ) に於てさ心鉒井困蜼で代官に願ひを出した文書があ

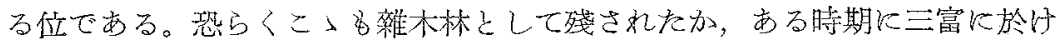

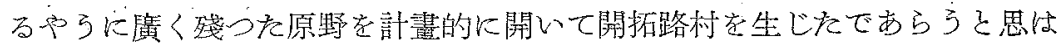

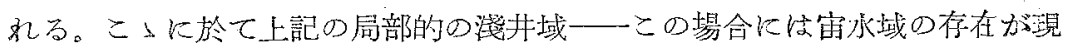

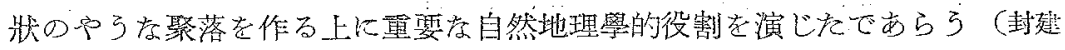

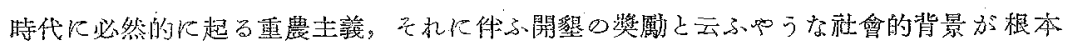
的の重琹性を有つてるたことは勡めて述べる迄るないう。

宙水域が上述のや引に梖北一西南又は東西の方间を有つてみるのも，新田

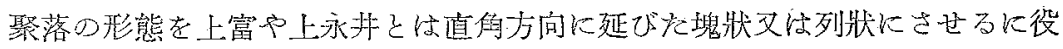
立つた8のと思子。故に形態的兒地から地下水(菑水) 制約性の聚落已呼多 ことが出來る。

柳瀨川の北側の懛地上にある新田聚落は等距離を隔てて配置されてねる

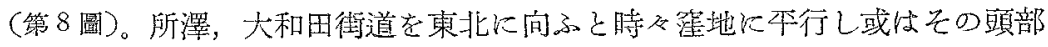
を橫切る所には必ず宙水を見，同時に新田聚落が發澾してねて，その間の平

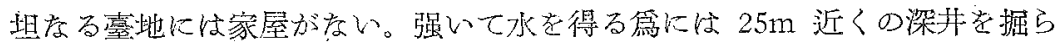

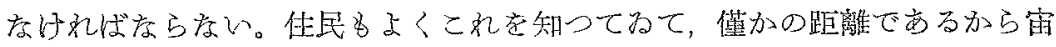

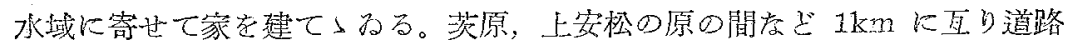

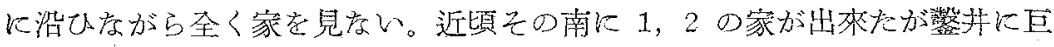

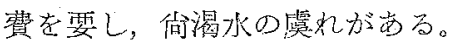

聚落が淺い窒地の內にあることは水を一壓得易くする上幾分でも冬の西北

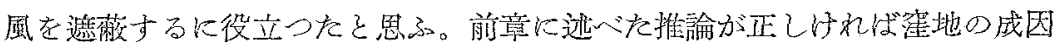

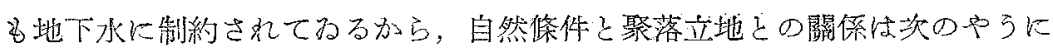


複雜在ものでする。

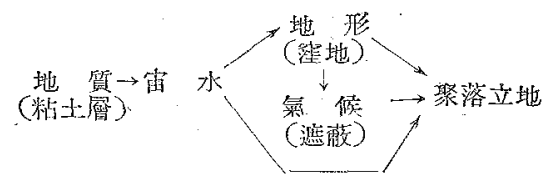

併し䇠地の底が高く，豪雨後には永が溜亲るので愛宕山などではこれを避け てなる。

普通家屋と并戸の位置は按近し，井曰は宅地中に掘られてるる。然るに愛 宿山及び和田原の一部支兩者が離れ，井戶列と街道に沿ふ家屋列とが相當の，

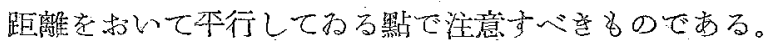

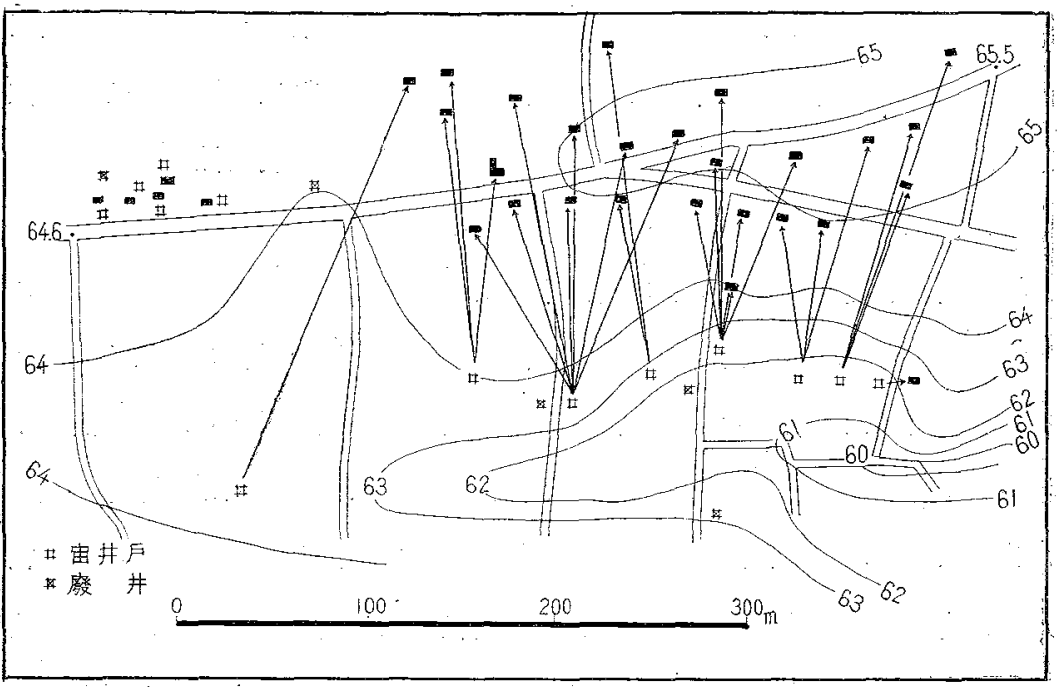

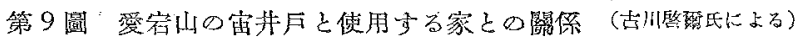

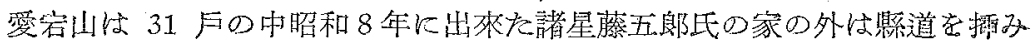

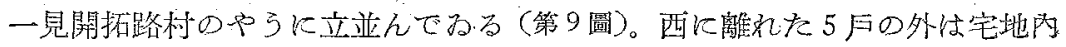

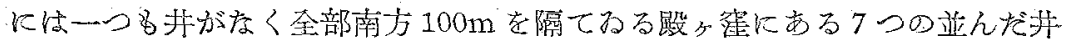

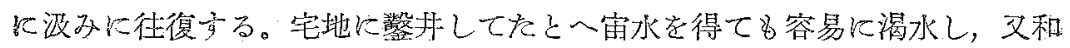


田原のやらに媣井月を作るなでには至つてね学い。宅地と井とが離礼てるる 原因については别文に私考在逝にる積りである。

和田原の大部分子窪地中にあり元は宙井曰を使用してみをが，水量不足し 大正 14 年 4 月共同の深并戸(澡さ $24.7 \mathrm{~m}$ ) を掘り，其後 3 つ深并月出出來

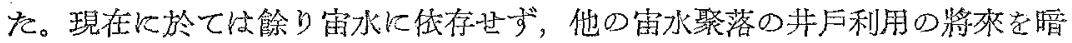

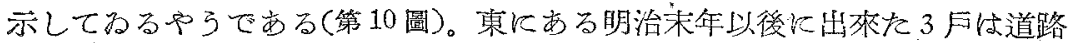

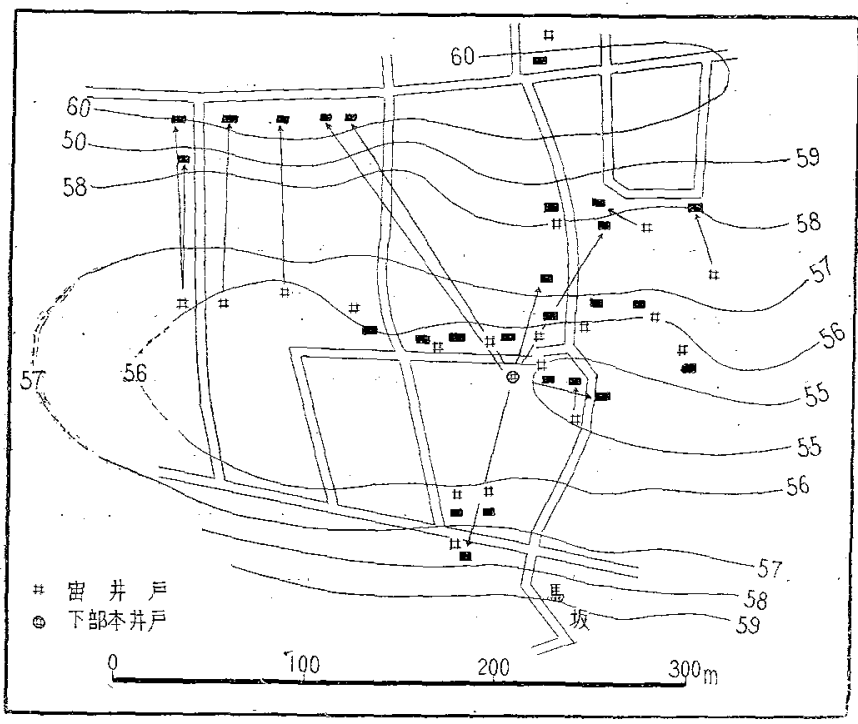

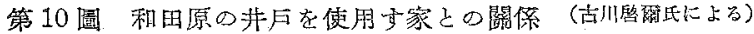

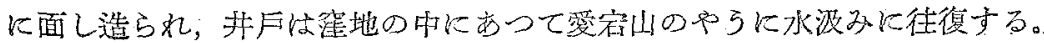

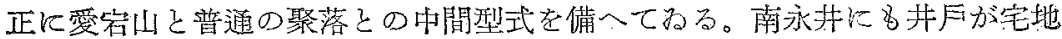
の处にあるるのるるが距離が短くて特筆する程のことない。

\section{結—論}

1)所澤町東部の武藏野囊地には細長く淺い窪地が西南西から東北杲に向ひ

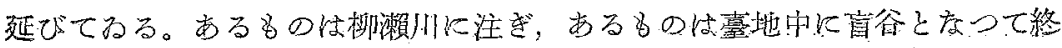


る。本時は流れ当河渠8大く底は烟火学つてるる。

2)この方面の地下水は上部，中部，下部背水の3つに分好万。

\begin{tabular}{|c|c|c|c|c|c|}
\hline 地过水 & 上部 帶 水 & 中部器 水 & 下 & 部 帶 & 水 \\
\hline 帶水 層 0 地質 & -2 & 砂 & 砂 & & 碎 \\
\hline 帶水厤下部の地筫 & 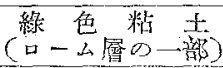 & 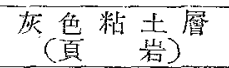 & & $\longrightarrow$ & \\
\hline 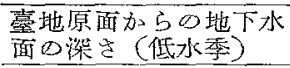 & $8 \mathrm{~m}$ & $15 \mathrm{~m}$ & & $23 \mathrm{~m}$ & \\
\hline 地下水 $の$ 性唕 & 雷 & $\begin{array}{l}\text { 本 水 (高水森) } \\
\text { 宙 水 (低水季) }\end{array}$ & 本 & & 水 \\
\hline 取水する井年 & 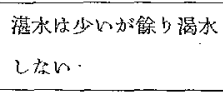 & 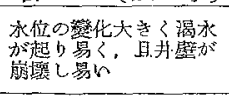 & 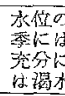 & 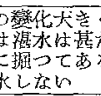 & 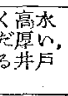 \\
\hline 范 & 淺い蓝地心附近 & 宙水の四周等 & & 日大堂地 & 原酒 \\
\hline
\end{tabular}

3）上記の淺い寉地は大體宙水域と一致し少くとも源には宙水を㒻る。

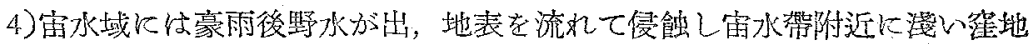

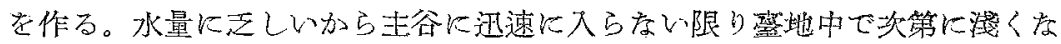
り盲谷をなつて渻失する。

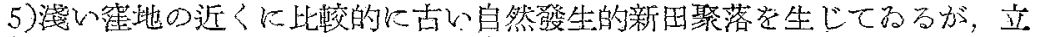

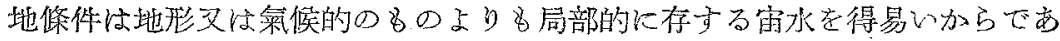
る。

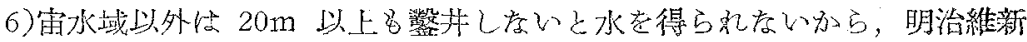

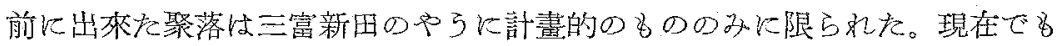
深井帶には新住宅が出來度い。しかし宙水域のあるものは人家の增加により 渴水し出し，深井曰が掘られて來をるのもるる。

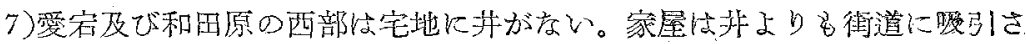

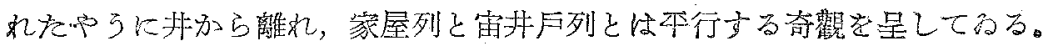

\section{參 考 交}

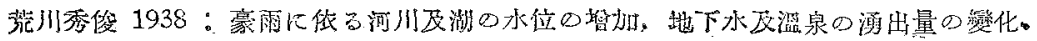


中央氣象臺策報，14，118-123.

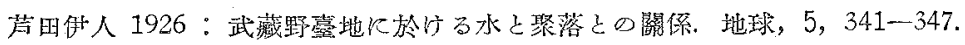

花井重次，千葉德爾 1939 ：關東本野の凹地地形に就いて。地理，2，147-158.

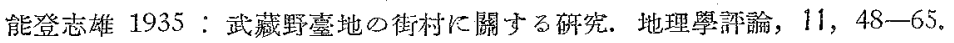

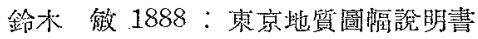

汇本芳郎 1937 ：相模野の地下水。陸水學襍誌，7，98--112.

Veatch, A. C. etc. 1906 : Underground water resources of Long Island, New York. U. S. Geol. Surv. Prof. Paper, 44.

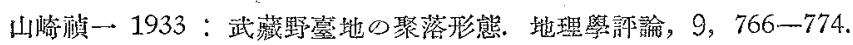

矢島仁吉 1935 ：武藏野臺地の地下水。䍀水學雜誌; 5, 125-136.

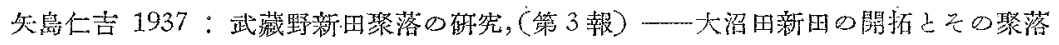

景觀. 地理殿奆, 27, 170-175, 289-294.

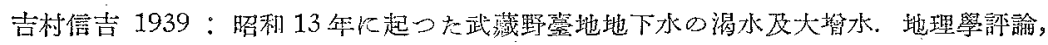

$15,165-187$.

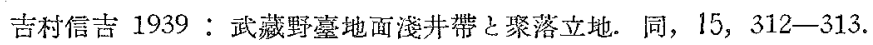

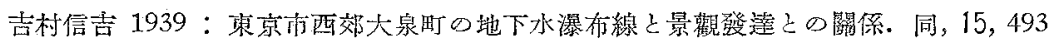
-508 .

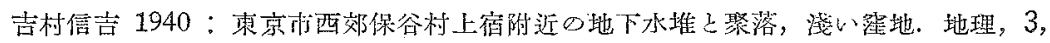
$82-95$.

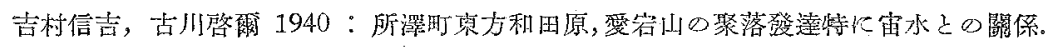
地理學, 8 。

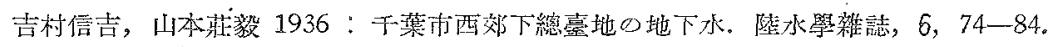

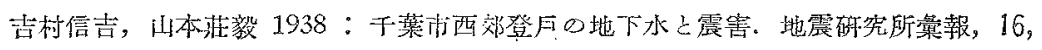
212-217. 